\title{
Targeted Sensitization as a Strategy to Reducing Loan Default in Microfinance Bank Operations in Yola, Adamawa State, Nigeria
}

\author{
Shuaib Jalaludeen ${ }^{1 *}$, Ferdinand Che ${ }^{1}$, Fatima Jalal-Eddeen ${ }^{2}$ \\ ${ }^{1}$ School of Business \& Entrepreneurship, American University of Nigeria, Yola, Nigeria \\ ${ }^{2}$ College of Continuing Education, Adamawa State Polytechnic, Numan, Nigeria \\ Email: *shuaibu.jalaludeen@aun.edu.ng
}

How to cite this paper: Jalaludeen, S., Che, F. and Jalal-Eddeen, F. (2018) Targeted Sensitization as a Strategy to Reducing Loan Default in Microfinance Bank Operations in Yola, Adamawa State, Nigeria. Open Access Library Journal, 5: e4275.

https://doi.org/10.4236/oalib.1104275

Received: December 20, 2017

Accepted: January 14, 2018

Published: January 17, 2018

Copyright $\odot 2018$ by authors and Open Access Library Inc.

This work is licensed under the Creative Commons Attribution International License (CC BY 4.0). http://creativecommons.org/licenses/by/4.0/

\section{Open Access}

\begin{abstract}
Background: In Nigeria and other developing countries, the main reason for poverty and uneven income and wealth distribution is low economic growth performance and low labor returns amongst others. The growing gap between the rich and the poor in the developing countries is alarming hence the need for government and policy makers to focus more toward ensuring a fair distribution of wealth among its populace. Although progress has been made toward poverty reduction in Nigeria, still more needs to be done to narrow this unacceptable gap so as to achieve the needed economic and social growth for society to thrive. In an attempt to address this gap, the central bank of Nigeria came up with the microfinance policy in 2004 and the sole purpose was to give micro, small and medium enterprises access to informal financial services to boost their capacity towards economic growth and development. However, the biggest threat to operations of the microfinance institutions is loan default, a situation where the clients do not fulfill payment of their credit facilities when due. Methods: This mixed method cross-sectional study used a questionnaire to collect responses from eligible persons. The participants in the survey are clients from three randomly selected microfinance institutions in Yola, Adamawa State, Nigeria. The collated data were analyzed using SPSS version 24 and simple Microsoft Excel to look at reasons for defaulting loan repayment and whether targeted sensitization has any significant role in reducing loan default rates. Results: Out of the 150 (100\%) questionnaires distributed, 70 (46.7\%) were returned and used for the analysis. Reasons for default in repayments revealed short repayment period (40\%), multiple loans (11.43\%), high-interest rates $(2.86 \%)$, family obligations $(20 \%)$ and poor business turnover (25.71). Of the 52.86 percent of the respondents who claim they were contacted by their respective microfinance institutions for sensitiza-
\end{abstract}


tion programs, 94.74 percent found the sensitization program helpful. Conclusion: This study has underscored the importance of targeted sensitization as an important strategy in reducing loan defaults in microfinance operations. Similarly, there is the need for further studies to look at the impact of multiple borrowing on loan repayment by the clients.

\section{Subject Areas}

Business Finance and Investment

\section{Keywords}

Microfinance Institutions, Loan Default, Targeted Sensitization, Adamawa State, Nigeria

\section{Introduction}

Nigeria, once considered among the top five oil producing nations across the globe [1] and with a GDP per capita of approximately $\$ 1000$ and GNI per capita of 5710 [2], its indicators of development in terms of poverty, gross national income and even distribution of resources are rather not encouraging. The growing gap between the rich and the poor is alarming, hence the need for the government to put in place policies that would ensure a fair distribution of wealth among the populace. It is interesting to note that, in the developing countries, some of the reasons for poverty and uneven income and wealth distribution are linked to low economic growth performance and low labour returns [3].

In Nigeria, record has shown that majority of the populace when they engage in one labor activity or the other do not get the required compensation needed to support themselves. As a result of the ineffectiveness of policies by governments of the developing countries to curtail these problems, the international community encouraged the developing economies to adopt the use of microfinance banks and institutions to address these challenges [4], as evidenced by the Grameen Foundation and Fundacion Paraguaya. The central bank, in Nigeria, came up with the microfinance policy in 2004 and the sole purpose was to give micro, small and medium enterprises access to informal financial services to boost their capacity towards economic growth and development [5]. It was also the objective of a subsequent microfinance policy enacted in 2005 to easily provide credit facilities and small loans to low income earners. The policy has gone a long way in springing up microfinance banks and institutions across the country to provide the said services.

Although there have been various personalities who have contributed to the development of microfinance institutions in the 1970's focusing more on less developed countries, modern microfinance started getting traction circa 1970 when Muhammed Yunus, the foremost professor of economics and Nobel Prize winner introduced his Grameen Bank concept of microfinance [6]. This has 
been cloned by countries worldwide after the realization of the fact that it is a very effective tool that can be used to reduce high poverty rates in the world. This is not to say that there hasn't been any form of formal lending practices going on over the years prior to his discovery although most of them were rather political than for a social cause. There are for instance the financial experiments, which led to the birth of cooperative societies in Europe in the mid $19^{\text {th }}$ century [7] and the then assistance of Latin Americans by left-wing US politicians to challenge the United States' imposition of capitalism on them, in the form of loans and reliefs [8].

In the Nigerian perspective, microfinance banks share loans through five stages (Figure 1), and according to Accion (2008), these stages are: the first which is "pre-disbursement" where machineries are put in place to prevent default, second which is "appraisals" where the potential clients are assessed and the third being the "verification" stage where they are vetted [9]. The fourth and last stages are the "disbursement" and the "repayment/collection stages" where the potential clients are invited for disbursement and are expected to pay up their loans respectively. When all these processes are followed, microfinance banks can reduce/totally prevent loan default and delinquency [9].

It is interesting to note that there are approximately 800 recognized microfinance banks and institutions in Nigeria, all of which the central bank acts as the regulator [10] [11]. These microfinance banks and institutions provide loanable funds and credit facilities to non-privileged members of the society, usually low-income earners who do not have or are not able to access formal financial services [12]. In addition, they are faced with problems, which hinder their operations thereby making them unable to achieve their objectives. The biggest threat to operations of the microfinance institutions is loan default, a situation where the clients do not fulfill payment of their credit facilities when due. However, the reasons for the default are due to reasons that include: multiple borrowing, client poaching by banks and lack of savings among others. This problem of high loan default rates continues to be the biggest threat to microfinance institutions, which if not properly examined, can drive them out of business [13]. It is expected that the microfinance banks and institutions should put some mechanisms in place such as appraisals and verification to prevent such from happening. Although the microfinance operators often directly engage their clients clearly stating the expectations to them through sensitization programs, loan defaults still take place. This forms the foundation of this research which hopes to determine the role that targeted sensitization plays in reducing loan default rates in microfinance bank operations in a rural Nigeria.

In determining this role, an effective sensitization program must first be outlined by the microfinance banks [13]. The conceptual framework which this

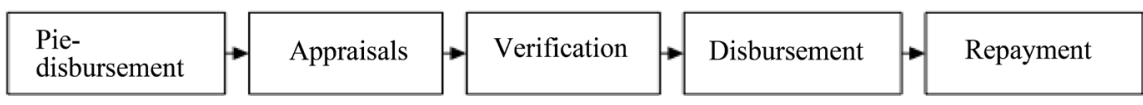

Figure 1. Showing the various stages of microfinance bank operations in Nigeria. 
study adopts states that when an effective sensitization program is deployed, it prevents factors such as client poaching, loan recycling, insufficient funds and loan pushing which lead to multiple borrowing [13]. As shown in Figure 2, targeted sensitization also tackles other factors such as lack of willful savings, poor supervision, high interest rates and time shortage which lead to loan default. The conceptual framework adds that multiple borrowing leads to loan default and vice versa. In any case of loan defaulting or multiple borrowing, the MFI is expected to walk the client back up through the sensitization process [13].

\section{Method}

This mixed method cross-sectional study used a questionnaire to collect responses from eligible persons. Research design is the foundation of every research work as it helps us know how to go about looking for information. This research used the mixture of descriptive research design and cross-sectional survey design, obviously because it is the most suitable way to describe the thoughts, feedbacks and inputs of various respondents. The survey research method, which is suitable with descriptive research design, is adopted for this research where questionnaires were used to draw information from respondents. In a case whereby a respondent is illiterate, interview was conducted.

The participants in the survey are clients from three randomly selected microfinance institutions in Yola, Adamawa State, Nigeria: Buyu Foundation, Hududullah Microfinance Institution, Standard Microfinance Bank. The population of Yola, Adamawa State is estimated at 400,000 [14], the vast majority (about 80\%) of whom are living below poverty line ( $\$ 2$ per day) [15]. So, approximately 40,000 are adults approximately $10 \%$ of whom probably patronize microfinance banks (i.e. under 5000).

The collated data were analyzed using SPSS version 24 and simple Microsoft Excel to look at reasons for defaulting loan repayment and whether targeted

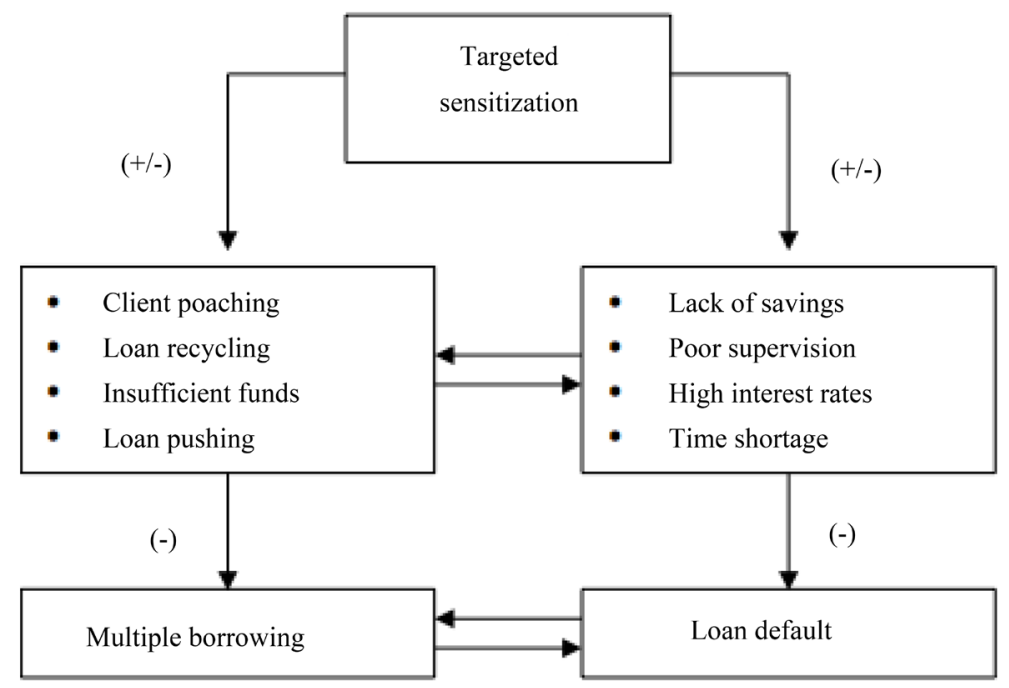

Figure 2. Depicting the conceptual framework for the study. 
sensitization has any significant role in reducing loan default rates.

The research questions for this research are:

RQ-Does targeted sensitization have any effect on loan default reduction?

The hypotheses of the proposed research, after review of relevant literature and the problem statement, are that:

$\mathrm{HO}_{1}$ - Targeted sensitization programs do not reduce microfinance bank loan default rates.

$\mathrm{H} 1_{1}$-Targeted sensitization programs reduce microfinance bank loan default rates.

The independent and dependent variables are "targeted sensitization" and "loan default rates" respectively. The sample size calculation required for generating representative population estimates was 96 (assuming a design effect of 1 , a confidence level of $95 \%$, an alpha of 5\%, and an estimated prevalence of 50\%). Over 150 questionnaires were administered in Yola and Jimeta but only a total of 70 valid responses were collated. The actual sampling method used was a nonprobability sampling somewhat convenient because of the limited time available to conduct the research. The main reason for collating 70 valid responses was because the clients were hard to track down as most of them rarely visited the bank premises except for when they encounter problems or during repayment periods.

\section{Results}

All analysis was done using the Statistical Package for the Social Sciences. Descriptive statistics tools such as frequency, mode and standard deviation were all used. Chi-square tests were also conducted with a $95 \%$ level of confidence, with the results presented in tabular forms below. Out of the 150 (100\%) questionnaires distributed, 70 (46.7\%) were returned and used for the analysis.

Table 1 shows males 37 (52.86\%) and females 33 (47.14\%), with males as higher borrowers with a Mode value of 1 . As shown in Table 2, majority of the respondents are in the age range of $36-45$ years 35 (50\%) while the least age group is 16 - 25 years 3 (4.29\%).

Table 3 is a classification of the respondents based on their levels of education. The majority of the respondents had either primary school education $32(45.71 \%)$ or no any formal education $14(20 \%)$.

In Table 4, the reasons for default in repayments revealed short repayment period $(40 \%)$, multiple loans $(11.43 \%)$, high-interest rates (2.86\%), family obligations (20\%) and poor business turnover (25.71).

As shown in Table 5, 37 (52.86\%) of the respondents were contacted by their respective microfinance institutions for sensitization programs and 33 (47.14\%) claimed they were not contacted.

Similarly, and as shown in Table $6,94.74 \%$ of the respondents claimed they found the sensitization program helpful and $5.26 \%$ of the respondents claimed they did not. 
Table 1. Gender of respondents.

\begin{tabular}{|c|c|c|c|c|c|}
\hline Value Label & Value & Frequency & Percent & Valid Percent & Cum Percent \\
\hline Male & 1 & 37 & 52.86 & 52.86 & 52.86 \\
\hline Female & 2 & 33 & 47.14 & 47.14 & 100.00 \\
\hline \multicolumn{2}{|c|}{ Total } & 70 & 100.0 & 100.0 & \\
\hline \multirow{2}{*}{\multicolumn{2}{|c|}{$N$}} & & Valid & & 70 \\
\hline & & & Missing & & 0 \\
\hline \multicolumn{2}{|c|}{ Mean } & & & & 1.47 \\
\hline \multicolumn{2}{|c|}{ Mode } & & & & 1.00 \\
\hline \multicolumn{2}{|c|}{ StdDev } & & & & 0.50 \\
\hline \multicolumn{2}{|c|}{ Minimum } & & & & 1.00 \\
\hline \multicolumn{2}{|c|}{ Maximum } & & & & 2.00 \\
\hline
\end{tabular}

Table 2. Age range of respondents.

\begin{tabular}{|c|c|c|c|c|c|}
\hline Value Label & Value & Frequency & Percent & Valid Percent & Cum Percent \\
\hline $16-25$ & 1 & 3 & 4.29 & 4.29 & 4.29 \\
\hline $26-35$ & 2 & 18 & 25.71 & 25.71 & 30.00 \\
\hline $36-45$ & 3 & 35 & 50.00 & 50.00 & 80.00 \\
\hline$>45$ & 4 & 14 & 20.00 & 20.00 & 100.00 \\
\hline Total & & 70 & 100.0 & 100.0 & \\
\hline \multirow[t]{2}{*}{$N$} & & \multicolumn{2}{|l|}{ Valid } & \multicolumn{2}{|c|}{70} \\
\hline & & \multicolumn{2}{|l|}{ Missing } & \multicolumn{2}{|c|}{0} \\
\hline Mean & & & & \multicolumn{2}{|c|}{2.86} \\
\hline Mode & & & & \multicolumn{2}{|c|}{3.00} \\
\hline StdDev & & & & \multicolumn{2}{|c|}{0.79} \\
\hline Minimum & & & & \multicolumn{2}{|c|}{1.00} \\
\hline Maximum & & & & \multicolumn{2}{|c|}{4.00} \\
\hline
\end{tabular}

\section{Discussions}

There is no doubt that microfinance banks and institutions continue to be plagued with a series of problems, the biggest of which is loan defaulting where by clients do not fulfill payment of their credit facilities when due. The outcome of this research has shown that majority of the respondents were males 37 (52.86\%) who are also the higher borrowers. It is interesting to note that most of the responders had only primary education $(45.71 \%)$ and within the age range of 36 45 years $(50 \%)$.

The fact that most of the borrowers had little education meant that most of them were poor with no good paying jobs to supplement their means of livelihood and afford basic amenities for themselves and their families. While most of 
Table 3. Level of education of respondents.

\begin{tabular}{|c|c|c|c|c|c|}
\hline Value Label & Value & Frequency & Percent & Valid Percent & Cum Percent \\
\hline None & 1 & 14 & 20.00 & 20.00 & 20.00 \\
\hline Primary school & 2 & 32 & 45.71 & 45.71 & 65.71 \\
\hline Secondary school & 3 & 12 & 17.14 & 17.14 & 82.86 \\
\hline Polytechnic/Uni. & 4 & 10 & 14.29 & 14.29 & 97.14 \\
\hline Other & 5 & 2 & 2.86 & 2.86 & 100.00 \\
\hline Total & & 70 & 100.0 & 100.0 & \\
\hline \multirow[t]{2}{*}{$N$} & \multicolumn{4}{|c|}{ Valid } & 70 \\
\hline & \multicolumn{4}{|c|}{ Missing } & 0 \\
\hline Mean & & & & & 2.34 \\
\hline Mode & & & & & 2.00 \\
\hline StdDev & & & & & 1.05 \\
\hline Min & & & & & 1.00 \\
\hline $\operatorname{Max}$ & & & & & 5.00 \\
\hline
\end{tabular}

Table 4. Reasons for lack of timely repayment.

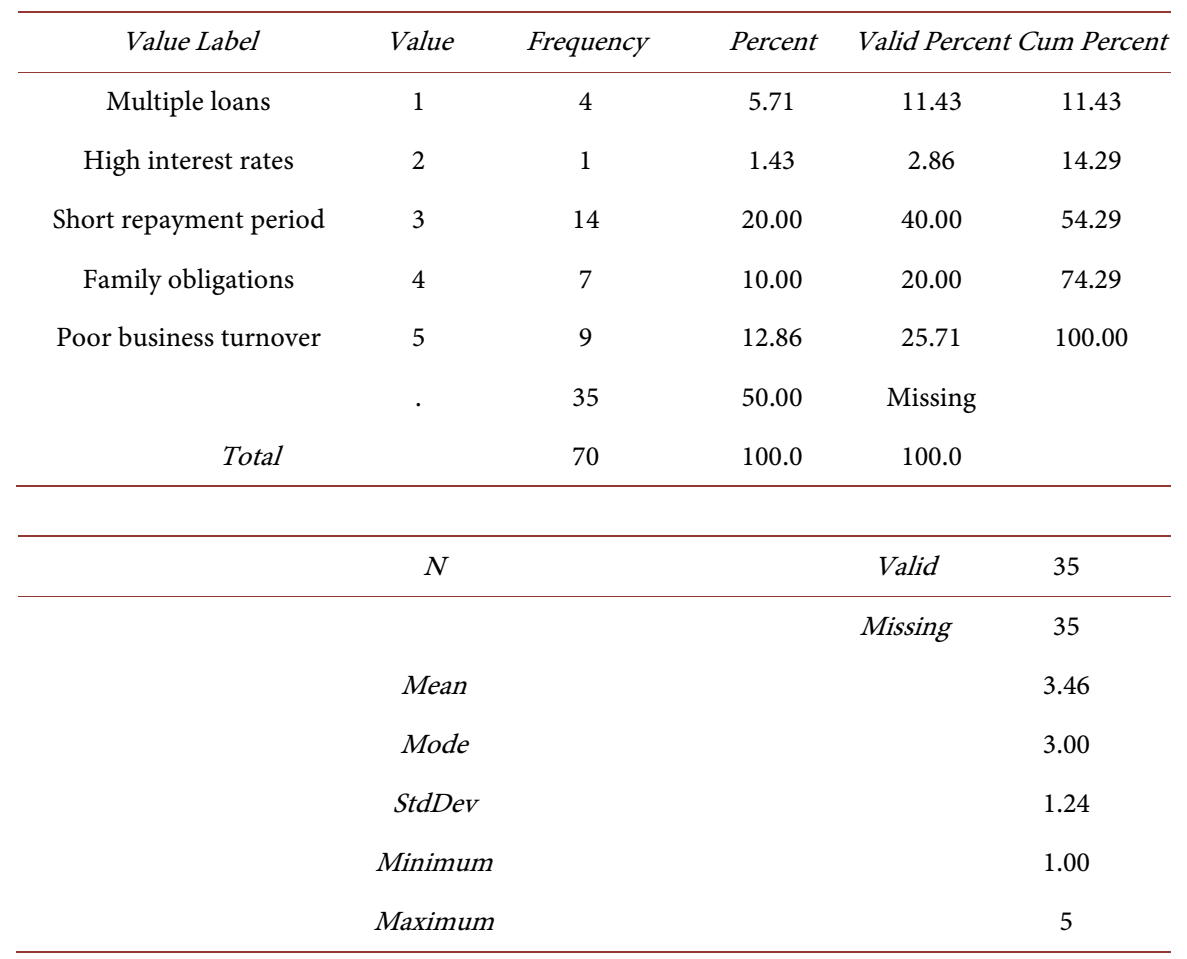

the reasons for the default in repayments were short repayment period (40\%), other responders also mentioned multiple loans (11.43\%), high-interest rates (2.86\%), family obligations (20\%) and poor business turnover (25.71) as other reasons for the default. 
Table 5. Targeted sensitization by microfinance banks.

\begin{tabular}{|c|c|c|c|c|c|}
\hline Value Label & Value & Frequency & Percent & Valid Percent & Cum Percent \\
\hline Yes & 1 & 37 & 52.86 & 52.86 & 52.86 \\
\hline No & 2 & 33 & 47.14 & 47.14 & 100.00 \\
\hline \multicolumn{2}{|c|}{ Total } & 70 & 100.0 & 100.0 & \\
\hline \multirow{2}{*}{\multicolumn{3}{|c|}{$N$}} & & Valid & 70 \\
\hline & & & & Missing & 0 \\
\hline \multicolumn{3}{|c|}{ Mean } & & & 1.47 \\
\hline \multicolumn{3}{|c|}{ Mode } & & & 1.00 \\
\hline \multicolumn{3}{|c|}{$S t d D e v$} & & & 0.50 \\
\hline \multicolumn{3}{|c|}{ Minimum } & & & 1.00 \\
\hline \multicolumn{3}{|c|}{ Maximum } & & & 2.00 \\
\hline
\end{tabular}

Table 6. Number of respondents who found sensitization helpful.

\begin{tabular}{|c|c|c|c|c|c|}
\hline Value Label & Value & Frequency & Percent & Valid Percent & Cum Percent \\
\hline Yes & 1 & 36 & 51.43 & 94.74 & 94.74 \\
\hline \multirow[t]{2}{*}{ No } & 2 & 2 & 2.86 & 5.26 & 100.00 \\
\hline & . & 32 & 45.71 & Missing & \\
\hline \multicolumn{2}{|l|}{ Total } & 70 & 100.0 & 100.0 & \\
\hline \multirow{2}{*}{\multicolumn{3}{|c|}{$N$}} & & Valid & 38 \\
\hline & & & & Missing & 32 \\
\hline \multicolumn{3}{|c|}{ Mean } & & & 1.05 \\
\hline \multicolumn{3}{|c|}{ Mode } & & & 1.00 \\
\hline \multicolumn{3}{|c|}{ StdDev } & & & 0.23 \\
\hline \multicolumn{3}{|c|}{ Minimum } & & & 1.00 \\
\hline \multicolumn{3}{|c|}{ Maximum } & & & 2.00 \\
\hline
\end{tabular}

Similarly, of the $37(52.86 \%)$ of the respondents that were contacted by their respective microfinance institutions for the sensitization programs, $94.74 \%$ of them claimed they found the sensitization program helpful.

Looking at the research question on if targeted sensitization has any effect on loan default reduction, it is clear from the responses that the $52.86 \%$ of respondents were contacted about sensitization programs and most of them found the program very helpful; they said they were satisfied with the terms and conditions and the explanations given to them. This further restates the fact that targeted sensitization programs have an effect on microfinance bank default rates and can reduce it hence the null hypothesis is rejected.

Thus, while the microfinance banks have designed a very good sensitization 
program seeing that most respondents were satisfied with the delivery, but there is a problem of effective implementation of the programs by microfinance banks. If they do not successfully capture all clients and sensitize them, they should not expect to reduce high default rates.

\section{Conclusion}

This study has underscored the importance of targeted sensitization as an important strategy in reducing loan defaults in microfinance operations. It is believed that with adequate sensitization to the clients, the issue of loan repayment default could be reduced to an appreciable level to help improve the developmental impact and the overall performance of the microfinance institutions. The recommendation here is that microfinance banks and institutions should develop and implement targeted sensitization programmes to especially prospective clients. Similarly, consideration should be given to a longer repayment period to the clients as a measure of reducing loan defaults. Still, there is the need for further studies to look at the impact of multiple borrowing on loan repayment by the clients.

\section{Limitations of the Study}

The study was limited by the following:

1) Limited number of respondents: The microfinance bank clients were hard to track down as most of them rarely visited the bank premises except for when they had problems or during repayment period. Similarly, the sensitization programs for the Microfinance bank clients were only done once and that was a long time ago, which also meant that the clients wouldn't have the need to show up again.

2) Reliability of respondents: Some of the respondents deliberately withheld information for fear that it might be shared with the Microfinance Banks hence they would be made to face the repercussions of their actions. Some of them were also not interested in filling out the questionnaires, so their reliability was questioned.

\section{Acknowledgements}

We acknowledge with gratitude the cooperation of the microfinance houses where this research was carried out.

We declare that there is no any potential conflict of interest or royalty associated with the manuscript.

We declare that no funding is received from any source for this research.

\section{References}

[1] Kazi, M.H. and Leonard, J.E. (2012) Microfinance, Poverty and Youth Unemployment of Nigeria: A Review. Global Journal of Human Social Science, Sociology, Economics \& Political Science, 12, 45-59.

https://globaljournals.org/GJHSS_Volume12/6-Microfinance-Poverty-and-Youth.pdf 
[2] Trading Economics (2016) Nigeria GDP. http://www.tradingeconomics.com/nigeria/gdp

[3] Olowa, W. (2012) Concept, Measurement and Causes of Poverty: Nigeria in Perspective. American Journal of Economics, 2, 25-36.

http://www.sapub.org/global/showpaperpdf.aspx?doi=10.5923/j.economics.2012020 $\underline{1.04}$ https://doi.org/10.5923/j.economics.20120201.04

[4] Okunmadewa, F. (1998) Domestic and International Response to Poverty Alleviation in Nigeria. Makurdi: Proceedings of the 7 th Annual Conference of the Zonal Research Units, Research Department of CBN.

[5] Nwaogazi A. (2010) Are Some MFBs Micro-Finance or Misfeasance Institutions. Daily Trust. http://www.microfinancenigeria.com

[6] Bateman, M. (2014) The Rise and Fall of Muhammad Yunus and the Micro Credit Model.

http://www.microfinancegateway.org/sites/default/files/mfg-en-paper-the-rise-andfall-of-muhammad-yunus-and-the-microcredit-model-jan-2014.pdf

[7] Birchall, J. (1994) Coop: The People’s Business. Manchester University Press, Manchester.

[8] Nye, J. (1990) Bound to Lead: The Changing Nature of American Power. Basic Books, New York.

[9] Accion (2008) Best Practices in Collections Strategies. InSight. http://www.smartcampaign.org/storage/documents/Tools_and_Resources/ACCIO N-_Best_Practice_in_Collection_Strategies.pdf

[10] CBN (n.d.) Microfinance. http://www.cenbank.org/devfin/Microfinance.asp

[11] CBN (n.d.) Supervision Framework. http://www.cenbank.org/Supervision/

[12] Nwanyanwu, O. (2011) Micro Finance in Nigeria: Problems and Prospects. African Research Review, 5, 87-103.

http://www.ajol.info/index.php/afrrev/article/viewFile/67307/55400 https://doi.org/10.4314/afrrev.v5i2.67307

[13] Mpogole, H., Mwaungulu, I., Mlasu, S. and Lubawa, G. (2012) Multiple Borrowing and Loan Repayment: A Study of Microfinance Clients at Iringa, Tanzania. Global Journal of Management and Business Research, 12, 96-102.

https://globaljournals.org/GJMBR_Volume12/10-Multiple-Borrowing-and-Loan-Re payment.pdf

[14] The Guardian (2015) Yola: The City Where People Fleeing Boko Haram Outnumber 400,000 Locals. The Guardian.

http://www.theguardian.com/world/2015/jan/28/boko-haram-nigeria-yola-refugees -monica-mark-adamawa

[15] Onu, J.I. and Abayomi, Z. (2009) An Analysis of Poverty among Households in Yola Metropolis of Adamawa State, Nigeria. Journal of Social Sciences, 20, 43-48. http://www.krepublishers.com/02-Journals/JSS/JSS-20-0-000-09-Web/JSS-20-1-000-0 9-Abst-PDF/JSS-20-01-043-09-699-Onu-J-I/JSS-20-01-043-09-699-Onu-J-I-Tt.pdf https://doi.org/10.4314/afrrev.v5i2.67307 